\title{
Peningkatan Hasil Belajar Luas Bangun Datar melalui Strategi Belajar Kooperatif Tipe Jigsaw bagi Siswa
}

\author{
Nurdasmi Nurdasmi
}

Sekolah Dasar Negeri 22 Tanah Keras Kecamatan Bayang

Article Info:

Accepted : October 2019

Published Online: November 2019

\begin{abstract}
Abtract
Implementation of learning through Jigsaw type cooperative learning is by steps: dividing students into groups consisting of 4-6 people each group called the original group. Each origin group member is given a different topic. Every original group member who gets the same topic joins a group called the expert group. In expert groups, students discuss topics to be discussed according to the instructions of the Student Worksheet (LKS). After the discussion, each member of the expert group rejoined the original group to explain the topic discussed in the expert group. From the results of research that researchers have done, it appears that student learning outcomes have improved. The average value of students on a base score of 5.06, the actions are taken in the first cycle increased with an average of 6.9. Then the action is held again in cycle II, with an average student score reaching 8.3. From the results of this study, it can be concluded that through Jigsaw cooperative learning can improve student mathematics learning outcomes in class V UPT SDN 22 Tanah Bayang District. Therefore, it is suggested that teachers can carry out the learning process through Jigsaw cooperative learning with the aim of being able to improve student learning outcomes and interests.
\end{abstract}

Keywords: Hasil Belajar, Belajar Kooperatif, Jigsaw

This is an open access article distributed under the Creative Commons Attribution License, which permits unrestricted use,
distribution, and reproduction in any medium, provided the original work is properly cited. C2019 by author

\section{PENDAHULUAN}

Seperti diketahui, era globalisasi sekarang ini menginginkan manusia yang mempunyai pola pikir yang logis dan kritis. Sebagaimana yang diutarakan Sri (2006:1) "bahwa matematika yang merupakan ilmu deduktif, aksiomatik, formal, hirarkis, abstrak, bahasa simbol yang padat arti adalah sebuah sistem matematika. Sistem matematika berisikan model-model yang dapat digunakan untuk mengatasi persoalan-persoalan nyata. Manfaat lainnya adalah dapat membentuk pola pikir orang yang mempelajarinya menjadi pola pikir matematis yang sistematis, logis, kritis dengan penuh kecermatan". Oleh sebab itu matematika sangat perlu dipahami dan dikuasai oleh semua lapisan masyarakat terutama siswa Sekolah Dasar (SD).

Tujuan pembelajaran matematika di atas menuntut siswa berfikir kritis dan kreatif. Untuk mewujudkan tujuan pembelajaran matematika, hendaknya guru berusaha melibatkan siswa secara aktif dalam kegiatan pembelajaran. Hal yang dapat dilakukan adalah guru menggunakan berbagai model pembelajaran agar siswa tidak merasa jenuh dalam menerima pembelajaran yang disampaikan.Berdasarkan observasi peneliti di kelas $\mathrm{V}$ UPT. SDN. 22 Tanah Keras Kecamatan Bayang pada tanggal 25 Juli 2019, siswa menganggap mata pelajaran matematika adalah mata pelajaran yang paling sulit di antara mata pelajaran lainnya, sehingga siswa kurang semangat dalam belajar matematika.

Fenomena yang peneliti dapatkan dari kelas V UPT. SDN. 22 Tanah Keras Kecamatan Bayang, dalam pembelajaran menghitung luas bangun datar guru hanya menjelaskan konsep-konsep dari materi yang akan diajarkan, kemudian memberikan latihan kepada siswa tentang materi yang telah dijelaskan tanpa menganalisis apakah siswa tersebut sudah paham atau belum. Guru kurang melibatkan siswa dengan alat peraga yang tepat dan cara mengajar yang digunakan masih bersifat konvensional, yaitu cendrung menggunakan metode ceramah. Sehingga pembelajaran lebih didominasi oleh guru yang menyebabkan siswa kurang aktif dalam proses 
pembelajaran.Melihat keunggulan dari pembelajaran kooperatif tipe Jigsaw, maka peneliti menggunakan pembelajaran kooperatif (cooperative learning) tipe Jigsaw dalam penelitian tindakan kelas dengan judul Peningkatan Hasil Belajar Luas Bangun Datar Melalui Strategi Belajar Kooperatif Tipe Jigsaw Bagi Siswa Kelas V UPT. SDN. 22 Tanah Keras Kecamatan Bayang.

\section{METODE}

Penelitian yang dilakukan adalah penelitian tindakan kelas dengan menggunakan pendekatan kualitatif. Jenis penelitian yang dilakukan adalah penelitian tindakan kelas (classroom Action Research) dibidang pendidikan khususnya dalam pengajaran matematika tentang luas bangun datar pada kelas V UPT. SDN. 22 Tanah Keras Kecamatan Bayang. Subjek Penelitian 24 orang yang terdiri dari 15 perempuan dan 11 laki-laki. Penelitian ini dilakukan pada semester dua bulan Januari s/d Juni tahun ajaran 2018/2019 pada kelas V UPT. SDN. 22 Tanah Keras Kecamatan Bayang. Pelaksanaan penelitian tindakan ini dimulai dari tanggal 24 Mei 2019 dan berakhir pada tanggal 10 Juni 2019. Penelitian ini dilakukan sebanyak 2 siklus dengan rentang waktu 3 kali pertemuan (9 jam pelajaran). Instrumen yang digunakan dalam melaksanakan penelitian ini untuk mendapatkan data adalah dengan menggunakan lembar observasi, hasil tes dan dokumantasi. Berupa gambaran tentang pengamatan terhadap praktisi dalam pembelajaran menghitung luas bangun datar di kelas V SD yang dicatat pada lembaran observasi. Analisis data dilakukan terhadap data yang telah direduksi baik data perencanaan, pelaksanaan maupun data evaluasi, secara terpisah-pisah. Hal ini dimaksud agar dapat ditemukan berbagai informasi yang spesifik dan terfokus pada berbagai informasi yang mendukung pembelajaran dan yang menghambat pembelajaran. Dengan demikian pengembangan dan perbaikan atas berbagai kekurangan dapat dilakukan tepat pada aspek yang bersangkutan.

\section{HASIL PENELITIAN} berikut :

Deskripsi pembelajaran melalui pembelajaran kooperatif tipe Jigsaw pada setiap siklus dirincikan sebagai

\section{Siklus I}

\section{Perencanaan}

Pelaksanaan siklus I pertemuan pertama dilaksanakan pada tanggal 24 Mei 2019 mulai pukul 07.30 sampai 09.15, dimana proses pembelajarannya dilaksanakan selama 105 menit (3 jam pelajaran). Sebelum melaksanakan pembelajaran, peneliti terlebih dahulu membuat persiapan yang terdiri dari Rencana Pelaksanaan Pembelajaran (RPP) dan Lembar Kerja Siswa (LKS).

\section{Pelaksanaan}

1. Pertemuan I

Pertemuan I pada siklus I dilaksanakan pada hari Jum'at tanggal 24 Mei 2019 mulai pukul 07.30 sampai 09.15. Pelaksanaan pembelajaran ini sesuai dengan rencana yang telah dibuat, yaitu dengan menggunakan pembelajaran kooperatif tipe jigsaw. Pada pertemuan I ini indikator yang dibahas adalah menemukan kembali rumus luas belah ketupat, jajar genjang, layang-layang dan trapesium.

a. Kegiatan awal

Pada pelaksanaan tindakan ini, peneliti bertindak sebagai guru.Tindakan ini diawali dengan mengucapkan salam, menyiapkan kondisi kelas yaitu meminta siswa untuk merapikan tempat duduknya, kemudian berdo'a secara bersama-sama serta absensi.

b. Kegiatan inti

Sebelum masuk pada materi yang akan dibahas, guru membagi siswa kedalam beberapa kelompok belajar (kelompok asal dan kelompok ahli). Kelompok asal terdiri dari 6 kelompok dan kelompok ahli terdiri dari 4 kelompok. Pembagian kelompok ini dilakukan dengan cara mengurutkan tingkat kemampuan akademiknya dari atas ke bawah yang dapat dilihat dari hasil tes dasarnya yang digolongkan ke dalam tingkat intelektual tinggi, sedang dan rendah.

Setelah siswa duduk dalam kelompok ahlinya masing-masing, guru membagikan dan LKS yang akan didiskusikan.. Dalam kelompok, guru juga memberikan media bangun-bangun datar yang terbuat dari karton berwarna yang berguna untuk proses menemukan kembali rumus luas dari bangun-bangun datar yang akan dibahas. Ketika berdiskusi guru memberikan bimbingan pada masing-masing kelompok, terutama kelompok yang mengalami kesulitan. Selesai berdiskusi guru meminta perwakilan masingmasing kelompok ahli untuk melaporkan hasil diskusi kelompoknya. 
Kemudian guru meminta siswa untuk bergabung kembali ke kelompok asal. Dalam kelompok asal ini masing-masing anggota kelompok menjelaskan topik yang telah dibahas dalam kelompok ahlinya sesuai dengan petunjuk LKS. Setelah menjelaskan, guru membimbing siswa untuk merangkum materi yang telah dibahas. Kemudian guru mengadakan tanya jawab dengan siswa tentang topik yang telah dibahas yang bertujuan untuk mengetahui tingkat pemahamannya. Pada kegiatan ini guru tidak memberikan tes, cukup dengan mengadakan tanya jawab saja. Karena dalam pertemuan I ini yang dituntut adalah siswa dapat menemukan kembali rumus luas bangun datar (belah ketupat, jajar genjang, layang-layang dan trapesium) dan pengaplikasian dari rumus yang telah ditemukan akan dibahas dalam pertemuan II.

c. Kegiatan akhir

Pada kegiatan ini, hal-hal yang dilakukan oleh peneliti adalah menyimpulkan pembelajaran bersama siswa serta memberikan catatan tentang topik yang telah dibahas. Kemudian meminta siswa berdo'a bersama untuk pulang. Pembelajaran pada pertemuan I ini telah selesai terlaksanakan berdasarkan semua langkah-langkah yang telah disusun.

\section{Pengamatan}

Proses pembelajaran ini diamati oleh teman sejawat, sedangkan proses pembelajarannya dilaksanakan oleh peneliti sendiri. Adapun kegiatan yang diamati adalah kegiata siswa dan guru saat proses pembelajaran berlangsung. Dari uraian tentang rambu-rambu karakteristik keberhasilan guru pada halaman sebelumnya, dapat diketahui bahwasannya untuk pertemuan I ini persentase mengajar dari aspek guru yaitu 67,5\% sedangkan pada aspek siswa baru mencapai $65,9 \%$.

\section{Pertemuan II}

Pertemuan II dalam pelaksanaan tindakan pada siklus I ini dilakukan pada tanggal 28 Mei 2019 mulai dari pukul 07.30 sampai 09.15.

a. Kegiatan awal

Tindakan ini diawali dengan mengucapkan salam, menyiapkan kondisi kelas, berdo'a serta absensi. Kemudian menyampaikan materi yang akan dibahas serta memberikan appersepsi yaitu tanya jawab tentang pelajaran pada pertemuan sebelumnya yaitu tanya jawab tentang rumus-rumus menghitung luas bangun datar (belah ketupat, jajar genjang, layang-layang dan trapesium).

b. Kegiatan inti

Dalam kegiatan ini, guru meminta siswa membentuk kelompok berdasarkan kelompok yang telah terbentuk. Setelah siswa duduk dalam kelompoknya (kelompok asal). Dalam kelompok ahli, guru memberikan Lembar Kerja Siswa (LKS) yang akan didiskusikan. Dalam berdiskusi, masing-masing anggota kelompok harus serius membahas topik dalam kelompoknya. Ketika berdiskusi guru memberikan bimbingan pada masing-masing kelompok, terutama kelompok yang mengalami kesulitan. Setelah selesai berdiskusi guru meminta perwakilan masing-masing kelompok untuk melaporkan hasil diskusi kelompoknya.Setelah masing-masing kelompok ahli selesai melaporkan hasil diskusinya, guru meminta siswa untuk bergabung kembali ke kelompok asal. Dalam kelompok asal ini masing-masing anggota kelompok menjelaskan topik yang telah dibahas dalam kelompok ahlinya sesuai dengan petunjuk LKS. Setelah masing-masing anggota kelompok selesai menjelaskan, guru membimbing siswa untuk merangkum materi yang telah dibahas. Kemudian guru mengadakan tanya jawab dengan siswa yang tentang topik yang telah dibahas yang bertujuan untuk mengetahui pemahamannya tentang topik yang telah dibahas. Tes ini diselesaikan secara bersama-sama dalam kelompok. Setelah selesai menjawab soal-soal, hasilnya diperiksa secara bersama-sama di dalam kelas. Bagi kelompok yang memperoleh nilai tertinggi diberikan penghargaan.

\section{Refleksi}

Berdasarkan hasil diskusi dengan guru kelas dan rekan sejawat, maka diperoleh hal-hal sebagai berikut:

1. Penyajian materi melalui pembelajaran kooperatif tipe Jigsaw sudah sesuai dengan rencana namun waktu yang digunakan terlalu singkat. Peneliti dan guru merasa dalam penggunaan pembelajaran tersebut masih memerlukan tambahan waktu dalam pelaksanaannya.

2. Hasil tes siklus I menunjukkan belum keseluruhan siswa memahami materi yang diberikan. Masih ada beberapa siswa yang masih mendapatkan nilai di bawah rata-rata. Setelah ditanyakan kepada siswa ternyata banyak yang menjawab tidak terlalu konsentrasi karena didesak waktu oleh guru, sehingga mereka belum paham dengan apa yang mereka pelajari.

Dari diskusi yang telah dilakukan dengan guru kelas dan teman sejawat, didapatkan kesimpulan bahwa pelaksanaan pembelajaran siklus I belum berhasil. Hal ini dibuktikan oleh rata-rata persentase ketuntasan hasil belajar siswa belum mencapai $61,53 \%$ 


\section{Siklus II \\ Perencanaan.}

Hasil analisis refleksi pada siklus I menunjukkan subjek penelitian belum mencapai tujuan pembelajaran khususnya yang diharapkan. Karena itu pembelajaran dilanjutkan dengan siklus II. Pembelajaran siklus II dilakukan agar siswa dapat memahami lebih lanjut tentang materi luas bangun datar. Pembelajaran siklus II dilaksanakan dalam satu kali pertemuan dengan alokasi waktu 4 x 35 menit.

\section{Tahap Pelaksanaan.}

Siklus II ini dilaksanakan pada hari Jum'at tanggal 31 Mei 2019 pukul 07.30-09.50 WIB. Pembelajaran siklus II berlangsung selama 140 menit.

\section{Kegiatan awal}

Peneliti memulai pembelajaran dengan mengucapkan salam, menyiapkan kondisi kelas, melakukan do'a bersama, pengambilan absensi siswa dan menyampaikan tujuan pembelajaran yang ingin dicapai. Peneliti kemudian memotivasi siswa dan melacak pemahaman dengan cara menanyakan tentang materi yang telah dipelajari pada pertemuan sebelumnya.

2. Kegiatan inti

Selanjutnya pembelajaran pada kegiatan inti dengan materi menyelesaikan masalah yang berkaitan dengan luas bangun datar melalui pembelajaran kooperatif tipe jigsaw. Hal-hal yang dilakukan pada kegiatan inti pada siklus II ini adalah sebagai berikut:

a. Membagi siswa ke dalam kelompok asal dan memberikan topik yang akan dipelajari, yaitu menyatakan soal cerita yang berkaitan dengan luas belah ketupat, jajar genjang, layang-layang dan trapesium

b. Membaca topik yang telah diterima. Kemudian setiap anggota yang memiliki topik yang sama berkumpul dalam satu kelompok yang disebut kelompok ahli.

c. Membagikan LKS tentang soal-soal cerita yang berhubungan dengan luas belah ketupat, layang-layang, trapesium dan jajar genjang. Dan menugaskan siswa berdiskusi sedangkan guru membimbing siswa dalam diskusi.

d. Selesai diskusi siswa diminta melaporkan hasil diskusinya. Ini bertujuan mengecek pemahamn siswa terhadap topik yang telah dibahas.

e. Menyuruh siswa kembali ke kelompok asal dan siswa menjelaskan topik yang dipelajari pada kelompok ahli kepada anggota kelompok asalnya.

f. Peneliti memberikan tes kepada masing-masing kelompok asal yang mencakup seluruh topik

g. Memberikan penghargaan kepada kelompok asal yang memperoleh nilai tertinggi.

Setelah terbentuk kelompok ahli, masing-masing kelompok ahli mendiskusikan topik yang akan dibahas, kemudian guru memberikan LKS yang berhubungan dengan soal cerita sesuai dengan topik ahli yang dibahas. Selesai diskusi perwakilan kelompok ahli melaporkan hasil diskusinya, setelah itu meminta masing-masing kelompok ahli bergabung ke kelompok asalnya.Setelah masing-masing ahli menjelaskan topik pada kelompok asalnya, guru memberikan tes pada masing-masing kelompok asal yang menyangkut seluruh topik.

\section{Kegiatan akhir}

Hal-hal yang dilakukan dalam kegiatan ini adalah menyimpulkan pembelajaran bersama siswam, memberikan evaluasi berupa tes menjawab soal-soal yang mencakup seluruh topik kepada seluruh siswa, yang bertujuan untuk mengetahui sejauh mana pemahaman siswa tentang materi yang baru diajarkan dan memberikan penghargaan pada kelompok asal yang memperoleh nilai tertinggi.

Selelai mengerjakan tes, guru mengumpulkan jawaban-jawaban siswa kemudian menjawabnya secara bersama-sama dan pengkoreksian jawabannya peneliti lakukan di rumah. Setelah membahas jawaban soal-soal tersebut, peneliti memberikan penghargaaan pada kelompok asal yang memperoleh nilai tertinggi saat mengadakan tes kelompok.

\section{Pengamatan}

1) Dari segi guru.

Alokasi waktu yang telah disusun sudah dapat dimanfaatkan dengan baik, mulai dari awal pelajaran sampai akhir pelajaran. Dalam membimbing diskusi guru telah melaksanakannya dengan baik, hal ini terlihat saat siswa melaksanakan diskusi siswa tenang dalam berdiskusi.

2) Dari segi siswa. 
a) Siswa terlihat serius dengan materi dan langkah yang dilaksanakan. b) siswa yang terpanggil ke depan kelas sudah bersedia untuk melaporkan hasil diskusinya. c) hasil diskusi siswa sudah terlihat baik,. d) soal tes yang dikerjakan siswa menampakkan siswa paham dengan masalah yang telah didiskusikan, terbukti dengan meningkatnya hasil belajar siswa.

Dari tabel pengamatan tentang rambu-rambu karakteristik pembelajaran menyelesaikan soal cerita yamg berhubungan dengan luas bangun datar di atas dapat kita lihat bahwasannya untuk siklus II ini persentase mengajar dari aspek guru sudah meningkat menjadi $90 \%$ sedangkan pada aspek siswa sudah mencapai 89,5\%.

\section{Refleksi}

Dari pengamatan peneliti dan observer pada siklus II, pelaksanaan penelitian pada umumnya sudah berjalan seperti yang diharapkan, kemungkinan besar disebabkan oleh siswa sudah terbiasa untuk melakukan diskusi. Refleksi terhadap perencanaan yakni sebagai berikut: dilihat dari hasil paparan siklus II diketahui bahwa perencanaan pembelajaran terlaksana dengan baik, dan langkah pembelajaran telah dilaksanakan dengan baik. Pada akhir pelajaran siklus II peneliti kembali mengadakan tes, tes diberikan secara individual.. Hasil analisis tes siswa pada akhir siklus II dapat dilihat pada tabel halaman berikut :

Tabel 4.21 Analisis Hasil Tes siswa Siklus II

\begin{tabular}{cccccc}
\hline $\begin{array}{c}\text { Banyak } \\
\text { Siswa }\end{array}$ & Nilai Terendah & Nilai Tertinggi & $\begin{array}{c}\text { Nilai Rata- } \\
\text { rata }\end{array}$ & $\begin{array}{c}\text { Banyak Siswa } \\
\text { yang Tuntas }\end{array}$ & $\%$ ketuntasan siswa \\
\hline $\mathbf{2 4}$ & 5 & 10 & 8,3 & 23 & $88,4 \%$ \\
\hline
\end{tabular}

Berdasarkan refleksi/diskusi yang dilakukan oleh peneliti dan dua orang observer, diperoleh kesimpulan bahwa dari 24 orang siswa yang mengikuti tes yang diadakan diakhir siklus II terdapat 23 orang yang mendapatkan nilai 7 keatas. Dimana rata-rata nilai siswa yang tuntas adalah 8,3 sedangkan rata-rata \% ketuntasan siswa mencapai $88,4 \%$. Sehingga dari hasil analisis tes siswa pada siklus II ini sudah dapat dikatakan tuntas, karena ketuntasan siswa sudah melebihi dari standar yang telah ditetapkan. Dari ketuntasan yang telah diperoleh dapat disimpulkan bahwa peneliti dalam pembelajaran siklus II telah melaksanakan tugas dengan baik. Hal ini dapat dibuktikan dengan adanya peningkatan hasil belajar siswa siklus II. Dengan demikian penelitian ini berhenti pada sliklus II

\section{PEMBAHASAN}

\section{Pembahasan siklus I.}

Pelaksanaan pembelajaran yang aktif dan menyenangkan sangat dibutuhkan oleh siswa Sekolah Dasar, pembelajaran yang menyenangkan itu dapat dilihat pada saat siswa bekerja sama dalam kelompok. Di dalam kelompok siswa saling tolong menolong, siswa dapat dengan mudah memahami materi pelajaran. Hal ini sesuai dengan yang terdapat dalam Nur (2006:12) menyatakan bahwa "Bembelajaran kooperatif mendasarkan suatu ide bahwa siswa bekerja sama dalam kelompok dan sekaligus bertanggungjawab pada aktivitas belajar anggota kelompoknya, sehingga seluruh anggota kelompok dapat menguasai materi pelajaran dengan baik".

Dalam Mohammad (2004:69) menyatakan bahwa langkah-langkah pembelajaran kooperatif tipe Jigsaw ada lima yaitu "Membaca topik ahli, diskusi kelompok ahli, laporan tim, kuis dan penghargaan tim". Berdasarkan pendapat tersebut peneliti telah melaksanakan langkah-langkah pembelajaran kooperatif tipe Jigsaw pada pelajaran matematika dengan materi menghitung luas bangun datar sesuai dengan rencana pembelajaran kooperatif tipe Jigsaw yang dirancang sendiri oleh peneliti, dengan langkah-langkah sebagai berikut : 


\section{Membaca topik ahli}

Hal pertama yang peneliti lakukan adalah membentuk siswa atas 6 kelompok. satu kelompok terdiri dari 4 orang siswa yang disebut dengan kelompok asal, pembagian kelompok siswa di dasarkan atas nilai yang diperoleh pada skor dasar dan jenis kelamin. Setelah kelompok terbentuk siswa diminta duduk dalam kelompoknya. Guru membagikan topik yang berbeda pada masing-masing anggota kelompok asal (kelompok asal 1, 2, 3 dan 4) yaitu tentang menemukan kembali rumus luas belah ketupat, jajar genjang, trapesium dan layang-layang dan dapat menghitung luas bangun datar tersebut sesuai dengan rumus untuk didiskusikan pada kelompok ahli dan menugasi siswa membacanya.

2. Diskusi kelompok ahli.

Masing-masing anggota kelompok asal yang mempunyai topik yang sama bergabung dalam satu kelompok yang disebut kelompok ahli (kelompok ahli belah ketupat, layang-layang, jajar genjang dan trapesium). Pada kelompok ahli, guru membagikan LKS sebagai petunjuk untuk diskusi, selanjutnya guru membimbing siswa dalam diskusi. Selesai diskusi guru menugasi siswa melaporkan hasil diskusi kelompok ahlinya tentang topik ahli yang telah dibahas ke depan kelas.

3. Diskusi kelompok asal

Selesai diskusi pada kelompk ahli siswa diminta bergabung kembali pada kelompok asal. pada kelompok asal siswa dituntut untuk berdiskusi menyampaikan topik yang dipelajari dalam kelompok ahli kepada anggota kelompok asalnya.

4. Tes

Langkah berikutnya adalah pemberian tes kepada masing-masing kelompok asal. Pemberian tes dilakukan diakhir pelajaran. guru memberikan 4 butir soal dan siswa menjawab pada kertas selembar yang telah disediakan oleh peneliti.

5. Penghargaan

Setelah memberikan tes, guru memberikan penghargaan bagi kelompok asal yang memperoleh nilai tertinggi. Dalam penelitian ini peneliti memberikan tingkat penghargaan kepada kelompok asal III dengan nilai kelompok 8 .

Dari analisis penelitian siklus I nilai rata-rata skor dasar 5,8. Setelah dilakukan tindakan nilai rata-rata siswa meningkat yaitu 6,9 .Berdasarkan hasil pengamatan siklus I yang diperoleh maka direncanakan untuk melakukan siklus II karena ada 10 orang anak yang memperoleh nilai di bawah rata-rata. untuk itu penelti melanjutkan penelitian pada siklus II.

\section{Pembahasan siklus II.}

Guru harus dapat memperhatikan perbedaan yang ada pada siswa karena tiap individu mempunyai karakteristik yang berbeda. Menurut Rochman Natawijaya (dalam Rosna, 2006:43) "Belajar adalah proses pembinaan yang terus menerus terjadi dalam diri individu yang tidak ditentukan oleh unsur ketururunan, tetapi lebih banyak ditentukan oleh faktor-faktor dari luar anak". Dalam belajar siswa banyak memperoleh dari guru, maka guru harus lebih memahami kembali ketiga aspek dalam pendidikan yaitu yang belajar, proses belajar dan situasi belajar. Adpun yang menjasi subjek belajar adalah anak didik atau siswa yang secara individu atau kelompok mengikuti proses pembelajaran dalam suasana tertentu.

Pembelajaran menyelesaikan masalah yang berkaitan dengan luas bangun datar pada siklus II ini, peneliti melakukannya sama seperti siklus I sesuai dengan perencanaan dan langkah-langkah pembelajaran kooperatif tipe Jigsaw sebagai bertikut :

a. Membaca topik ahli

Pada siklus II guru tidak lagi memberikan tes awal kepada siswa, karena skor akhir dari siklus I peneliti jadikan skor awal pada siklus II. Dan guru tidak membentuk kelompok siswa yang baru, guru hanya menugasi siswa duduk pada kelompok asal dan guru memberikan topik yang berbeda pada anggota masingmasing kelompok asal (kelompok asal 1,2, 3 dan 4) yaitu menyelesaikan masalah yang berkaitan dengan 
luas bangun datar (soal cerita tentang luas belah ketupat, layang-layang, jajar genjang dan trapesium), selanjutnya guru menugasi siswa membaca topik yang telah diberikan

b. Diskusi kelompok ahli.

Masing-masing anggota kelompok asal yang mempunyai topik yang sama bergabung dalam satu kelompok yang disebut kelompok ahli (kelompok ahli belah ketupat, layang-layang, jajar genjang dan trapesium). Pada kelompok ahli, guru membagikan LKS sebagai petunjuk untuk diskusi, selanjutnya guru membimbing siswa dalam diskusi. Pada siklus II guru lebih membimbing siswa secara merata dan lebih memperhatikan kebutuhan siswa, sehingga siswa lebih semangat pada saat diskusi. Selesai diskusi guru menugasi siswa melaporkan hasil diskusinya ke depan kelas.

c. Diskusi kelompok asal

Selesai diskusi pada kelompk ahli siswa diminta bergabung kembali pada kelompok asal. pada kelompok asal siswa dituntut untuk berdiskusi menyampaikan topik yang dipelajari dari kelompok ahli kepada anggota kelompok asalnya.

d. Tes

Langkah berikutnya adalah pemberian tes kepada kepada semua kelompok asal. Pemberian tes dilakukan diakhir pelajaran. guru memberikan 4 butir soal dan siswa menjawab pada kertas selembar yang telah disediakan peneliti.

e. Penghargaan

Dari hasil analisis penelitian siklus II nilai rata-rata kelas mencapai 8,3 berikut peneliti sajikan grafik peningkatan nilai rata-rata kelas dari siklus I ke siklus II

Pada siklus I nilai rata-rata kelas 6,9 yang digambarkan dengan diagram batang warna hijau. Setelah dilakukan tindakan pada siklus II nilai rata-rata siswa meningkat menjadi 8,3 yang digambarkan dengan diagram batang warna kuning. Berdasarkan hasil pengamatan siklus II yang diperoleh maka pelaksanaan siklus II sudah baik dan guru sudah berhasil dalam usaha peningkatan hasil belajar siswa dalam pembelajaran penyelesaian masalah yang berkaitan dengan luas bangun datar dengan menggunakan pendekatan kooperatif tipe jigsaw bagi siswa kelas V UPT SDN 22 Tanah Keras Kecamatan Bayang Kabupaten Pesisir Selatan.

Pada saat peneliti melakukan penelitian, peneliti mengambil skor dasar dari nilai rata-rata ujian mid semester II kelas V, dimana nilai rata-rata kelas hanya 5,8 yang dapat dilihat pada diagram batang warna biru. Kemudian peneliti melakukan tindakan siklus I dalam pembelajaran dengan menggunakan Model Pembelajaran Kooperatif tipe jigsaw nila rata-rata siswa meningkat hingga 6,9 yang digambarkan dengan diagram batang warna kuning. Setelah dilanjutkan dengan siklus II nilai rata-rata siswa meningkat menjadi 8,3 yang digambarkan dengan diagram batang warna merah. BSNP (2006:12) "kriteria ketuntasan untuk masing-masing indikator dalah $75 \%$. Namun disamping itu setiap satuan pendidikan harus manentukan kriteria ketuntasan minimal dengan mempertimbangkan tingkat kemampuan rata-rata siswa, kompleksitas kompetensi serta kemampuan sumber daya pendukung dalam penyelenggaraan pembelajaran”. Dari hal itu peneliti mengambil ketuntasan yang diterapkan di UPT SDN 22 Tanah Keras Kecamatan Bayang, yaitu pada mata pelajaran matematika standar ketuntasan minimalnya adalah $70 \%$ Berdasarkan hal itu penelitian ini berakhir di siklus II karena standar ketuntasan klasikalnya sudah melebihi dari target yang ditetapkan.

Pembelajaran yang disajikan pada siklus II, guru dalam memberikan motivasi sangat bagus. Pada proses pembelajaran guru banyak memberikan kesempatan kepada siswa untuk berdiskusi bersama dan bertanya tentang permasalahan yang tidak dimengerti oleh siswa. Untuk itu guru harus mampu menciptakan situasi yang menyenangkan untuk belajar. Sehingga hasil belajar siswa meningkat. Untuk mencapai hal tersebut sudah seharusnya guru mampu menciptakan pembelajaran yang sesuai dengan kebutuhan siswa. Selain itu, guru juga harus memperhatikan keberhasilan siswa dalam memahami sesuatu dengan cara sesuai dengan tingkat kemampuan siswa. Guru bertugas membelajarkan siswa. Untuk membelajarkan siswa tersebut guru haruslah menggunakan berbagai macam cara agar pembelajaran dapat bermakna bagi siswa, seperti menggunakan pendekatan pembelajaran yang bervariasi, media pembelajaran yang sesuai dengan tujuan dan menciptakan suasana belajar yang menyenangkan bagi siswa. 


\section{KESIMPULAN}

Dari paparan data dan hasil penelitian serta pembahasan pada halaman terdahulu, maka peneliti dapat menarik beberapa kesimpulan, yaitu:Perencanaan Pembelajaran menghitung luas bangun datar melalui Pembelajaran Kooperatif tipe Jigsaw disesuaikan dengan langkah-langkah melalui pembelajaran kooperatif tipe Jigsaw yaitu: membagi kelompok (kelompok asal dan kelompok ahli), membaca topik ahli, diskusi kelompok ahli, laporan kelompok ahli, tes/kuis, dan penghargaan.Pelaksanaan pembelajaran melalui pembelajaran kooperatif tipe Jigsaw dilaksanakan sesuai dengan perencanaan yang telah disusun, dimana langkah-langkah pembelajarannya dilaksanakan dalam tiga kegiatan pembelajaran yaitu kegiatan awal, kegiatan inti dan kegiatan akhir. Pembelajaran kooperatif tipe Jigsaw dapat membuat siswa lebih aktif dalam belajar, dapat meningkatkan sikap kerja sama karena pembelajarannya dilakukan secara berkelompok. Hal ini dapat terlaksana karena masing-masing anggota kelompok harus menguasai topik yang telah dibahas dan menyampaikan topik itu kepada anggota kelompoknya. Dengan kata lain pembelajaran kooperatif tipe Jigsaw dapat menumbuhkan tanggung jawab siswa terhadap materi yang dipelajarinya dan harus mengajarkan materi tersebut kepada temannya, sehingga siwa termotivasi untuk aktif dan serius dalam pembelajaran. Meningkatnya hasil belajar siswa dapat dilihat dari rata-rata nilai siswa dari tes awal 5,8 meningkat pada siklus I menjadi 6,9 pembelajaran belum dianggap tuntas jika hasil yang diperoleh di bawah $70 \%$ dan untuk itu penelitian ini dilanjutkan pada siklus II. Ternyata Pelaksanaan tindakan pada siklus II mengalami peningkatan yakni 8,3 yang sudah melebihi dari standar ketuntasan minimalnya. Hal ini merupakan bukti dari pelaksanaan penelitian yang telah dilakukan di UPT. SDN. 22 Tanah Keras Kecamatan Bayang telah berhasil.

\section{DAFTAR RUJUKAN}

Anas Sudijono. 2007. Pengantar Evaluasi Pendidikan. Jakarta : PT Raja Grafindo Persada

Antonius Cahya Prihandoko. 2006. Pemahaman dan Penyajian Konsep Matematika Secara Benar dan Menarik. Jakarta : Depdiknas

Aristo Rahadi. 2003. Media Pembelajaran. Jakarta : Depdiknas

Badan Standar Nasional Pendidikan (BSNP). 2006. BSNP. Jakarta : BSNP

Badan Standar Nasional Pendidikan (BSNP). 2016. Kurikulum Tingkat Satuan Pendidikan (KTSP). Jakarta : BSNP

Depdiknas. 2005. Materi Pelatihan Terintegrasi Matematika. Jakarta : Depdiknas

Erman Suherman, dkk. 2003. Strategi Pembelajaran Matematika Kontemporer. Bandung : JICA

Etin Solihatin. 2007. Cooperative Learning Analisis Model Pembelajaran IPS. Jakarta : Bumi Aksara

Harun Rasyid, dkk. 2007. Penilaian Hasil Belajar. Bandung : CV Wacana Prima

I.G.A.K Wardani, dkk. 2002. Penelitian Tindakan Kelas. Jakarta : Universitas Terbuka

Indriyastuti. 2016. Matematika Kelas III SD. Jawa Timur ; PT. Tiga Serangkai Pustaka Mandiri

Karso,dkk.1998.Materi pokok pendidikan matematika I.Jakarta: universitas Terbuka

Kunandar. 2016. Guru Profesional Implementasi KTSP dan Sukses dalam Sertifikasi Guru. Jakarta : PT. Raja Grafindo Persada

Masnur Muslich. 2007. KTSP Dasar Pemahaman dan Pengembangan. Jakarta: Bumi Aksara

Mohammad Nur. 2005. Pembelajaran Kooperatif. Surabaya : Depdiknas

Mulyana. 2007 . Tip dan Trik Berhitung Super Cepat dengan Konsep Rahasia Matematika. Surabaya : Agung Media Mulya

Nur Asma. 2006. Model Pembelajaran Kooperatif. Jakarta : Depdiknas

Nur Asma. 2016. Model Pembelajaran Kooperatif. Padang: UNP Pres

Sri Subarinah. 2006. Inovasi Pembelajaran Matematika Sekolah Dasar. Jakarta : Depdiknas

Suharsimi Arikunto, dkk. 2004. Evaluasi Program Pendidikan. Jakarta : PT.Bumi Aksara

Ritawati Mahyuddin, dkk. 2016. Hand Out Metodologi Penelitian Tindakan Kelas. Padang : UNP

Rochman Natawijaya. 1992. Psikologi Pendidikan. Jakarta : Depdikbud

Rosna. 2006. Peningkatan Hasil Belajar Geometri Dalam Penbelajaran melalui Penggunaan Media Bangun

Datar bagi Siswa Kelas IV SDN 18 Kota Panjang. Skripsi tidak diterbitkan. Padang.PGSD.UNP.

Wina Sanjaya. 2016. Strategi Pembelajaran. Jakarta : Kencana Prenada Media Group

Zahara Djafar. 2001. Konstribusi Strategi Pembelajaran Terhadap Hasil Belajar. Padang : FIP UNP 